\title{
ANALISIS DAMPAK ENSO (EL-NINO SOUTHERN OSCILLATION) TERHADAP TINGKAT KEKERINGAN UNTUK TANAMAN PANGAN DAN PALAWIJA \\ (STUDI KASUS : SULAWESI SELATAN)
}

Impact Analysis of ENSO (EI Nino-Southern Oscillation) on the Level of Drought for Food Crop and Secondary Food Crops (Case Study : South Sulawesi)

\author{
Yon Sugiarto ${ }^{1}$, Dori Kurniawan ${ }^{2}$ \\ ${ }^{1}$ Geofisika dan Meteorologi, FMIPA - IPB, Kampus IPB Darmaga Bogor, \\ ${ }^{2}$ Program Studi Meteorologi Terapan, Departemen Geofisika dan Meteorologi, FMIPA - IPB \\ email: yons@ipb.ac.id
}

\begin{abstract}
Weather and climate variability is a long-term weather changes that are characterized by fluctuations and deviations from normal conditions. One possible cause is the ENSO (EI-Nino Southern Oscillation) which affected in drought events. This research was conducted to determine and analyze the level of drought in South Sulawesi due to the influence of ENSO and compare the production of food crops and secondary food crops in normal years and ENSO. Drought index is calculated based on the Palmer method by using data of rainfall, air temperature and soil moisture as input. Based on the calculations using the method of Palmer drought index, the regions with monsoon rain patterns have a range of values between -22.71 drought until 18:23, Equatorial patterns ranging from -4.03 to 5:07, and on local patterns ranged from -8.57 until 10:07. Verification test results on the drought index of crop production data showed that each ENSO event is always followed by a decline in rice production, especially of rice fields. Food crop production generally tends to increase at each ENSO event because most crops are plants that are resistant to drought, particularly local varieties that have adapted well to their environment. Thus, the drought caused by the influence of ENSO can affect the production of food crops and secondary food crops.
\end{abstract}

Key Words : climate variability, drought, ENSO, food crops, Palmer index.

\section{PENDAHULUAN}

Secara geografis, Indonesia Indonesia merupakan daerah yang potensial dengan keterdiaan sumberdaya air yang melimpah sepanjang tahun. Sumber daya air merupakan komponen penting bagi aktivitas di berbagai sektor termasuk diantaranya pertanian. Sumberdaya air terkait dengan variabilitas iklim wilayah. Variabilitas iklim wilayah salah satunya ditandai oleh fluktuasi unsur-unsur iklim dari tahun ke tahun dan pada waktu tertentu yang dapat menyimpang dari kondisi normalnya. Salah satu bentuk penyimpangan yang terjadi adalah curah hujan yang berada di bawah normal pada periode waktu tertentu dan terkadang dengan rentang waktu yang sangat panjang.

Salah satu fenomena iklim yang berpengaruh dalam variabilitas iklim di wilayah Indonesia adalah ENSO (El-Nino Southern Oscillation). Fenomena EL-Nino yang terjadi berpotensi besar menyebabkan curah hujan jauh di bawah kondisi normal. ENSO adalah meningkatnya suhu muka laut di sekitar Pasifik Tengah dan Timur sepanjang ekuator dari nilai rata-ratanya. Kejadian tersebut ditandai dengan melemahnya angin pasat dan bergesernya

Penyerahan naskah $\quad: 2$ November 2009

Diterima untuk diterbitkan : 3 Desember 2009 
pusat konvergensi siklus Walker sebagai akibat dari peningkatan suhu muka laut tersebut. Fenomena ENSO ini akan mengakibatkan kekeringan yang sangat nyata di sebagian besar wilayah Indonesia (Boer 1999).

Kekeringan menggambarkan kondisi kekurangan air yang terjadi dalam jangka waktu tertentu (bulan atau tahun). Hal tersebut terjadi karena suatu wilayah menerima curah hujan di bawah rata-ratanya. Periode kekeringan yang terjadi dapat memiliki pengaruh yang signifikan terhadap lingkungan, pertanian, kesehatan, serta memiliki konsekuensi ekonomi dan sosial. Besaran dampak bervariasi sesuai dengan kerentanan wilayah yang terkena. Batasan kekeringan berbeda-beda bergantung pada latar belakang serta perhatian ataupun dampak yang diperhitungkan terkait dengan hubungan antara kebutuhan dan ketersediaan air. Dalam bidang pertanian, kekeringan diartikan dengan berkurangnya lengas tanah yang dibutuhkan oleh tanaman selama masa tanam. Sebagai contoh, petani tadah hujan cenderung memiliki kerentanan yang tinggi terhadap dampak kekeringan yang terjadi karena tidak adanya alternatif sumber air. Dampak kekeringan menjadi sangat besar jika terjadi di daerah sentra produksi pertanian tanaman pangan di Indonesia seperti Pulau Jawa dan Bali, sebagian wilayah Pulau Sumatera dan Sulawesi Selatan.

Pertanian tanaman pangan dan palawija merupakan dua bentuk pertanian yang memiliki respon berbeda terhadap gejala kekurangan air. Pertanian tanaman pangan umumnya sangat memerlukan ketersedian air yang tinggi selama fase pertumbuhan dan perkembangannya. Pertanian palawija memiliki respon yang berbeda terhadap gejala kekurangan air, karena tanaman palawija merupakan tanaman yang tahan terhadap kondisi tersebut. Dengan kata lain, ketersedian air yang melimpah apabila dikelola dan di manfaatkan dengan baik akan memberikan dampak yang sangat positif, khususnya di bidang pertanian.

Faktor lain yang membedakan antara pertanian pangan dan palawija adalah berdasarkan waktu tanamnya. Pertanian tanaman pangan yang mengkonsumsi air lebih banyak sangat cocok apabila dilakukan pada musim penghujan. Sedangkan pada musim kemarau dimana terjadi penurunan curah hujan, pertanian palawija sangat baik untuk dijadikan alternatif karena air tanaman yang diperlukan sedikit, tidak sebanyak pertanian tanaman pangan. Gejala kekurangan air dan penentuan waktu tanam suatu komoditas pertanian dapat dikaji berdasarkan tingkat kekeringan suatu wilayah akibat fluktuasi curah hujan. Fluktuasi curah hujan inilah yang lebih dominan menetukan naik atau turunnya hasil produksi komoditas pertanian di suatu wilayah, sehingga perlu dipahami dan dikaji lebih jauh.

Palmer (1965) mencoba memanfaatkan data iklim berupa curah hujan, suhu udara dan kelengasan tanah sebagai peubah untuk menduga tingkat kekeringan di suatu wilayah yang dinyatakan sebagai Indeks Palmer. Indeks ini dapat digunakan sebagai salah satu parameter untuk menentukan perubahan tingkat kekeringan pada suatu daerah dengan menggunakan prinsip neraca air yang telah banyak digunakan di banyak wilayah di dunia. 
Yon Sugiarto dan Dori Kuniawan

Indeks Palmer dapat menunjukkan indeks terlalu basah atau terlalu kering dari keadaan normalnya pada suatu daerah dengan pengklasifikasian menggunakan angka. Apabila indeks menunjukkan angka yang positif atau lebih besar dari nol, maka daerah tersebut bersifat basah dan tidak mengalami kekeringan. Semakin besar nilai indeks tersebut, maka kondisi daerah tersebut akan akan semakin ekstrim basah. Sebaliknya apabila indeks menunjukkan angka yang negatif atau lebih kecil dari nol, maka daerah tersebut bersifat kering dan dinyatakan mengalami kekeringan. Semakin kecil nilai indeks tersebut, maka kondisi daerah tersebut akan semakin ekstrim kering atau dengan kata lain daerah tersebut mengalami kekeringan yang sangat nyata. Menurut National Drought Mitigation Center (2006), Indeks Palmer sangat baik dan lebih memberikan prediksi kekeringan yang signifikan apabila diterapkan pada area yang luas dan daerah dengan topografi yang seragam, sehingga cakupannya lebih luas.

Provinsi ini memiliki karateristik iklim dengan pola hujan yang bervariasi antar wilayah terutama antara daerah pesisir barat dan pesisir timur. Provinsi ini juga memiliki kerentanan terhadap varibilitas iklim, terutama sebagai dampak fenomena ENSO. Selain itu Provinsi Sulawesi Selatan merupakan salah satu sentra produksi pangan nasional selain Pulau Jawa. Pada tahun 2005 dan 2006, total luas lahan sawah yang terkena kekeringan mencapai 13,625 ha, sedangkan yang puso mencapai 670 ha. Sebagai salah satu sentra produksi pangan, maka potensi bencana kekeringan yang terjadi dapat menyebabkan kehilangan besar dari produksi pangan secara nasional yang dapat mengancam ketahanan pangan nasional.

\section{Tujuan}

1. Menentukan tingkat kekeringan di Sulawesi Selatan.

2. Menganalisis pengaruh ENSO terhadap tingkat kekeringan di Sulawesi Selatan.

3. Membandingkan produksi tanaman pangan dan palawija pada tahun-tahun normal dan ENSO.

\section{METODOLOGI}

Data yang diperlukan dalam penelitian ini adalah sebagai berikut; Data curah hujan bulanan 1985-2002 dan data suhu rata-rata bulanan 1985-2002 (sumber : BMKG), data produksi tanaman pangan dan palawija wilayah Sulawesi Selatan (sumber : BPS), peta jenis tanah untuk Sulawesi Selatan (sumber : Bakosurtanal). peta tataguna lahan untuk wilayah Sulawesi Selatan (sumber : Pusat Vulkanologi dan Mitigasi Bencana Geologi) dan peta topografi daerah penelitian yang mencakup tata letak stasiun yang di analisis untuk memperoleh data lintang, bujur, dan ketinggian (sumber : http://srtm.csi.cgiar.org). Indeks Palmer yang digunakan untuk menunjukkan indeks kebasahaan atau kekeringan dari keadaan normalnya pada suatu daerah dengan pengklasifikasian menggunakan angka (Tabel 1). 
Tabel 1 Kelas indeks kekeringan dan sifat cuaca (Palmer, 1965)

\begin{tabular}{cc}
\hline Indeks Kekeringan & Sifat Cuaca \\
\hline$\geq 4.00$ & Ekstrem basah \\
$3.00-3.99$ & Sangat basah \\
$2.00-2.99$ & Agak basah \\
$1.00-1.99$ & Sedikit basah \\
$0.50-0.99$ & Awal selang basah \\
$0.49-(-0.49)$ & Normal \\
$-0.50-(-0.99)$ & Awal selang kering \\
$-1.00-(-1.99)$ & Sedikit kering \\
$-2.00-(-2.99)$ & Agak kering \\
$-3.00-(-3.99)$ & Sangat kering \\
$\leq-4.00$ & Ekstrem kering \\
\hline
\end{tabular}

\section{Tahapan Penelitian}

Penelitian ini terbagi menjadi beberapa tahap, yaitu pendugaan kapasitas air tersedia berdasarkan jenis tanah dan tataguna lahan, pendugaan evapotranspirasi potensial (ETp). Perhitungan neraca air untuk menduga koefisien paremeter iklim berdasarkan nilai ETp dan curah hujan, serta penentuan indeks kekeringan menggunakan indeks Palmer dimana sebelumnya telah dilakukan plotting sebaran stasiun hujan terlebih dahulu berdasarkan peta dasar provinsi Sulawesi Selatan. Tahap selanjutnya adalah menentukan korelasi antara curah hujan dan indeks Palmer menggunakan korelasi silang. Tahap paling akhir adalah analisis perbandingan kekeringan pada tahun-tahun normal dan ENSO serta implikasinya terhadap produktivitas tanaman pangan dan palawija.

\section{Pendugaan Kapasitas Air Tersedia (KAT)}

Pendugaan nilai Kapasitas Air Tersedia (KAT) pada tahap ini dilakukan dengan cara overlay terhadap peta jenis tanah dan peta tataguna lahan sehingga diperoleh perkiraan luas wilayah yang digunakan serta jenis tanah untuk setiap wilayah tersebut.

Lapisan tanah yang digunakan terdiri dari dua jenis, yaitu lapisan tanah bagian atas sedalam $\pm 25 \mathrm{~cm}$ dan lapisan tanah bagian bawah yang dalamnya sesuai dengan zona perakaran tanaman. Nilai KAT dapat diduga menggunakan bantuan tabel pendugaan KAT dari Thornthwaite dan Mather (1957). Selanjutnya nilai KAT untuk setiap lapisan tanah dapat dihitung menggunakan persamaan sebagai berikut :

$K A T_{1}=L \times K A T_{j} \times T_{1}$

dimana :

$$
\begin{array}{ll}
\mathrm{KAT} T_{1} & =\text { Kapasitas air tersedia tiap lapisan }(\mathrm{mm}) \\
\mathrm{L} & =\text { Persentase penggunaan lahan } \\
\mathrm{KAT}_{\mathrm{j}} & =\text { Kapasitas air tersedia pada jenis tanah }(\mathrm{mm} / \mathrm{m}) \\
\mathrm{T}_{1} & =\text { Tebal lapisan tanah }(\mathrm{m})
\end{array}
$$


Yon Sugiarto dan Dori Kuniawan

\section{Pendugaan Evapotranspirasi Potensial (ETp)}

Evapotraspirasi potensial diduga dengan menggunakan data suhu rata-rata bulanan yang diperoleh dari seluruh stasiun yang ada di wilayah Sulawesi Selatan. Apabila terdapat wilayah yang tidak memiliki stasiun, maka dilakukan asumsi untuk menduga suhu pada wilayah tersebut yaitu apabila ketinggian tempat naik 100 m dari permukaan laut, maka suhu akan turun sebesar $0,6^{\circ} \mathrm{C}$ yang diduga dari stasiun terdekat dengan wilayah tersebut.

Pendugaan ETp dapat dilakukan dengan menggunakan metode Thornthwaite (Chang 1968 dalam Turyanti 1995) sebagai berikut :

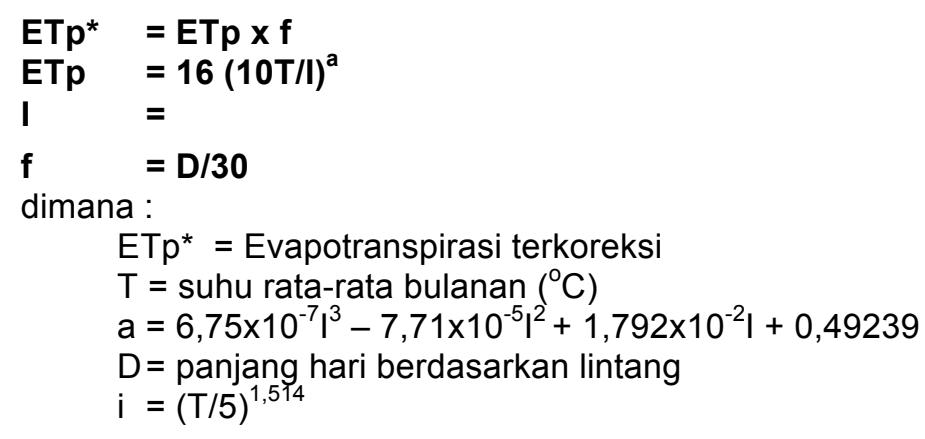

\section{Perhitungan Neraca Air dan Indeks Kekeringan}

Perhitungan neraca air menggunakan asumsi yaitu lengas tanah pada lapisan atas tidak akan masuk ke lapisan bawah sebelum jenuh, dan sebaliknya lengas pada lapisan bawah tidak akan keluar apabila lengas pada lapisan atas belum habis. Selain itu, perlu diperhitungkan juga loss, recharge, evapotranspirasi aktual dan limpasan permukaan (runoff). Limpasan permukaan dapat terjadi apabila kedua lapisan telah mencapai kapasitas lapang. Penghitungan neraca air ini ditujukan untuk menghitung konstanta-konstanta yang mendefinisikan karakteristik iklim, yaitu :
1. $\alpha \quad$ : koefisien evapotranspirasi
2. $\beta \quad$ : koefisien recharge
3. $\quad \mathrm{Y}$ : koefisien runoff
4. $\delta \quad$ : koefisien loss
5. $\mathrm{K} \quad$ : pendekatan pertama terhadap faktor pembobot $\mathrm{K}$

Analisis klimatologi jangka panjang perlu dilakukan untuk menurunkan kelima koefisien iklim (Hounam et al. 1975). Koefisien-koefisien tersebut digunakan untuk menduga presipitasi terjadi pada bulan-bulan sebelumnya yang diasumsikan sebagai kondisi normal yang mengacu pada ketersediaan air. Besarnya evapotranspirasi pada bulan tersebut, menggunakan persamaan berikut :

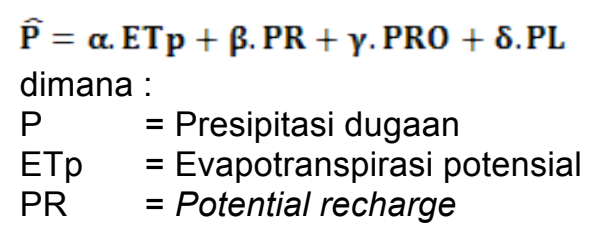


PRO = Potential runoff

$\mathrm{PL} \quad=$ Potential loss

Kenormalan nilai curah hujan sangat bergantung pada perhitungan cadangan air dan evapotranspirasi bulan sebelumnya. Selisih antara curah hujan pengamatan dan curah hujan dugaan diwakili oleh huruf $\mathrm{d}$. Apabila selisih tersebut dikalikan dengan faktor pembobot $\mathrm{K}$, maka akan diperoleh nilai indeks anomali lengas yang diwakili oleh huruf $Z$. Indeks kekeringan akhir $(X)$ bergantung pada nilai $Z$ sebelumnya dengan persamaan empiris:

$$
\begin{aligned}
X & =(Z / 3)_{j-1}+\Delta x \\
\operatorname{dimana} ; \Delta x & =(Z / 3)_{j}-0.103(Z / 3)_{j-1}
\end{aligned}
$$

\section{Analisis Korelasi}

Curah hujan merupakan faktor utama yang mempengaruhi kering tidaknya suatu wilayah. Hubungan antara kedua peubah tersebut ditunjukkan oleh koefisien korelasinya. Menurut Panofsky dan Brier (1958), rumus yang digunakan untuk menghitung korelasi antara dua deret waktu adalah korelasi silang (Cross correlation) atau dengan rumus "lag-cross correlation" dengan rumus masing-masing sebagai berikut :

$$
\begin{aligned}
& \mathbf{r}=\frac{\overline{\mathbf{P}_{(\mathrm{t})} \times \mathbf{X}_{(\mathrm{t})}}-\overline{\mathbf{P}_{(\mathrm{t})}} \times \overline{X_{(t)}}}{\mathbf{S}_{\mathrm{p}} \times \mathbf{S}_{\mathbf{x}}} \\
& \mathbf{r}_{\mathrm{L}}=\frac{\overline{\mathbf{P}_{(\mathrm{t})} \times \mathbf{X}_{(\mathrm{t}+\mathrm{L})}}-\overline{\mathbf{P}_{(\mathrm{t})}} \times \overline{X_{(t)}}}{\mathbf{S}_{\mathrm{p}} \times \mathbf{S}_{\mathrm{x}}}
\end{aligned}
$$

Keterangan :

$$
\begin{array}{ll}
r & =\text { Koefisien korelasi } \\
r_{\mathrm{L}} & =\text { Koefisien korelasi "lag" } \\
\mathrm{P}_{(\mathrm{t})} & =\text { Curah hujan pada waktu ke- } \mathrm{t} \\
\mathrm{X}_{(\mathrm{t})} & =\text { indeks kekeringan pada waktu ke- } \mathrm{t} \\
\mathrm{X}_{(\mathrm{t}+\mathrm{L})} & =\text { indeks kekeringan pada waktu ke } \mathrm{t}+\mathrm{L} \\
\mathrm{S}_{\mathrm{p}} & =\text { simpangan baku data curah hujan } \\
\mathrm{S}_{\mathrm{x}} & =\text { simpangan baku data indeks kekeringan }
\end{array}
$$

Analisis ini dilakukan untuk menguji keeratan hubungan antara fluktuasi curah hujan dan indeks kekeringan yang selanjutnya digunakan untuk menghitung fluktuasi produktivitas tanaman pangan dan palawija yang akan di analisis. Dengan persamaan tersebut dapat dlihat ada atau tidaknya keterlambatan respon terhadap penurunan dan peningkatan curah hujan. Korelasi silang pada lag0 untuk mengetahui pengaruh curah hujan pada bulan tersebut, lag1 untuk mengetahui pengaruh curah hujan pada bulan sebelumnya, serta lag2 untuk mengetahui pengaruh curah hujan pada dua bulan sebelumnya terhadap fluktuasi indeks kekeringan. 


\section{Verifikasi Indeks Kekeringan}

Verifikasi atau uji kelayakan indeks kekeringan terhadap produksi tanaman dilakukan untuk mengetahui konsistensi sebaran nilai indeks kekeringan yang diperoleh di wilayah Sulawesi Selatan.

\section{HASIL DAN PEMBAHASAN}

\section{Kondisi Klimatologis}

Provinsi Sulawesi Selatan memiliki keragaman tipe curah hujan yang berbeda dengan daerah lain. Sulawesi Selatan memiliki tiga pola iklim berbeda, yaitu monsunal, equatorial dan lokal. Sulawesi Selatan bagian utara diwakili oleh stasiun Plant Site dan Desa Malili yang memiliki pola hujan equatorial. Di bagian tengah terdapat stasiun Hasanudin dan Malino yang mewakili tipe pola curah hujan monsunal, sedangkan dua stasiun lainnya yang berada di bagian selatan yaitu Bikeru dan Tanah Kongkong memiliki tipe iklim lokal.

Selain memiliki keragaman tipe curah hujan, Sulawesi Selatan juga memiliki keragaman topografi. Keragaman tersebut secara tidak langsung akan berpengaruh terhadap kondisi klimatologis di daerah tersebut. Kondisi klimatologis yang paling berpengaruh di wilayah tersebut adalah curah hujan dan suhu. Sejalan dengan hasil penelitian De Boer (1948 dalam Sudibyakto 1985) kecenderungan distribusi curah hujan akan semakin meningkat seiring dengan bertambahnya ketinggian tempat dari permukaan laut. Namun demikian, ada pula beberapa stasiun hujan yang tidak sesuai dengan pernyataan tersebut. Kondisi ini diduga akibat adanya pengaruh topografi lokal dan pola iklim di daerah tersebut.

Rata-rata curah hujan dan suhu udara bulanan yang berasal dari 30 stasiun di Sulawesi Selatan (Gambar 1), dapat disimpulkan bahwa pola distribusi curah hujan tahunan di provinsi Sulawesi Selatan cenderung berpola monsunal, dimana curah hujan tertinggi terjadi pada bulan Januari dan terendah pada bulan September. Sementara itu, suhu tertinggi terjadi pada bulan Oktober dan terendah pada bulan Juli

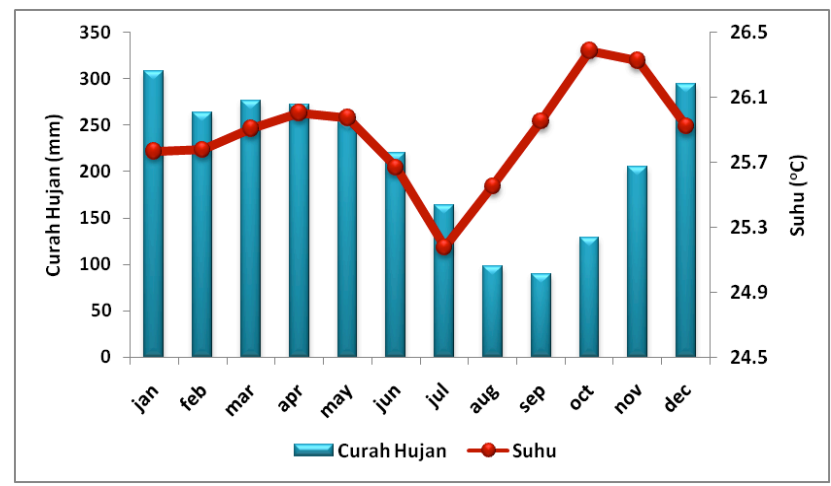

Gambar 1 Hubungan antara suhu dan curah hujan rata-rata provinsi Sulawesi Selatan. 


\section{Pendugaan Kapasitas Air Tersedia (KAT)}

Pendugaan kapasitas air tersedia sangat bergantung pada tekstur tanah. Tekstur tanah di wilayah Sulawesi Selatan sangat beragam, mulai dari lempung berliat, lempung berpasir, hingga lempung berdebu, namun pada umumnya bertekstur liat (Departemen Pertanian 1967). Diantara enam stasiun terpilih, stasiun yang berada di wilayah bagian utara cenderung didominasi oleh hutan dan lahan terbuka dengan persentase antara $40-70 \%$ dari luas daerahnya, dan sisanya merupakan kawasan pemukiman penduduk, sawah, tegalan dan lain-

lain. Pada daerah ini KAT lapisan atas berkisar antara 30-60 mm,sedangkan KAT lapisan bawah berkisar antara $180-320 \mathrm{~mm}$.

Stasiun yang berada di bagian tengah didominasi oleh hutan, tegalan dan lahan terbuka. Pada daerah ini KAT lapisan atas berkisar antara 50-70 mm, sedangkan KAT lapisan bawah berkisar antara $170-210 \mathrm{~mm}$. Sementara itu stasiun yang berada di wilayah bagian selatan lebih didominasi oleh lahan pertanian kering (tegalan) dan sawah, serta sisanya berupa hutan, pemukiman penduduk, lahan terbuka dan sebagainya. Pada daerah ini KAT lapisan atas berkisar antara 30-60 mm, sedangkan KAT lapisan bawah berkisar antara 130-150 mm.

\section{Perhitungan Neraca Air}

Perhitungan neraca air yang dihitung pada setiap stasiun yang mewakili pola hujan berbeda akan menghasilkan beberapa parameter koefisien neraca air yaitu koefisien evapotranspirasi $(\alpha)$, koefisien recharge $(\beta)$, koefisien runoff $(\gamma)$, koefisien loss $(\delta)$. Selanjutnya parameterparameter tersebut digunakan dalam perhitungan indeks Palmer.

Koefisien evapotranspirasi $(\alpha)$ adalah nilai yang menggambarkan besarnya evapotranspirasi yang terjadi di suatu wilayah. Nilai a berkisar antara 0 (bulan kering) sampai 1 (bulan basah). Secara umum, wilayah Sulawesi Selatan memiliki nilai a rataan bulanan sebesar 0.64 yang berarti evapotranspirasi aktual terjadi lebih dari $60 \%$ dan melebihi nilai evapotranspirasi potensialnya. Stasiun Malino dan Hasanudin yang mewakili pola hujan monsun, nilai $\alpha$ terendah terjadi pada saat memasuki bulan September yang merupakan bulan kering dengan nilai koefisien sekitar 0.5 dan nilai tertinggi 1 pada bulan basah antara Desember hingga Mei (Gambar 2). Stasiun Plant Site dan Desa Malili dengan pola hujan equatorial memiliki fluktuasi nilai $\alpha$ yang hampir sama dengan pola hujan monsun. Namun, pada pola hujan equatorial nilai a terbesar baru dicapai pada saat memasuki bulan Maret dengan keterlambatan hampir dua bulan, dan mengalami penurunan pada bulan Juni, setelah itu kembali naik memasuki bulan September. Sedangkan untuk stasiun dengan pola curah hujan lokal, nilai $\alpha$ berkebalikan dengan kedua pola hujan lainnya. 


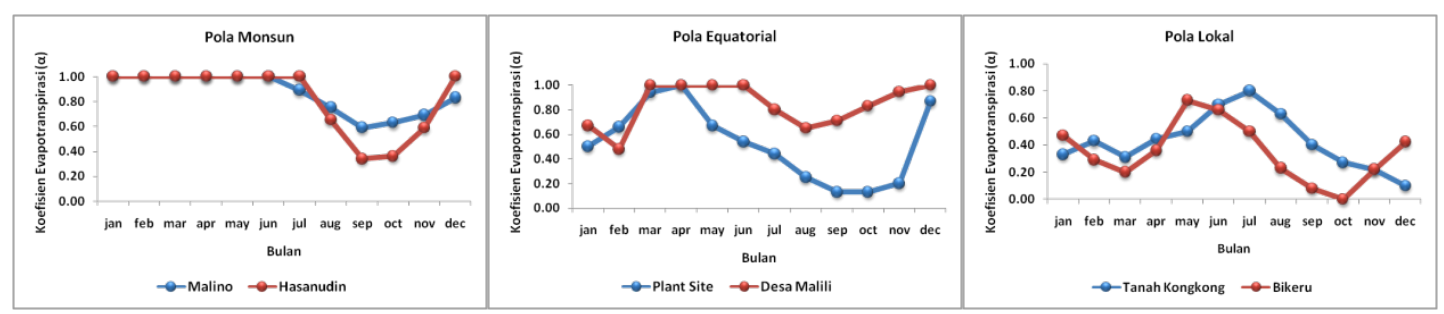

Gambar 2 Fluktuasi koefisien evapotranpirasi $(\alpha)$ dari enam stasiun di Sulawesi Selatan

Koefisien recharge $(\beta)$ menggambarkan seberapa besar pengisian air tanah pada saat terjadi hujan hingga mencapai kapasitas lapang. Kisaran nilai $\beta$ adalah 0 sampai 1 . Stasiun dengan pola hujan monsun dan equatorial, nilai $\beta$

menurun memasuki bulan April (Gambar 3). Hal ini karena memasuki bulan April hampir di semua stasiun mengalami penurunan curah hujan, sehingga nilai $\beta$ akan semakin defisit akibat sedikitnya curah hujan yang jatuh ke permukaan tanah. Sedangkan pada stasiun dengan pola hujan lokal mengalami kenaikan nilai $\beta$. Hal ini disebabkan karena adanya pengaruh faktor lokal seperti vegetasi dan tekstur tanah, sehingga curah hujan tetap tinggi meskipun musim kemarau.

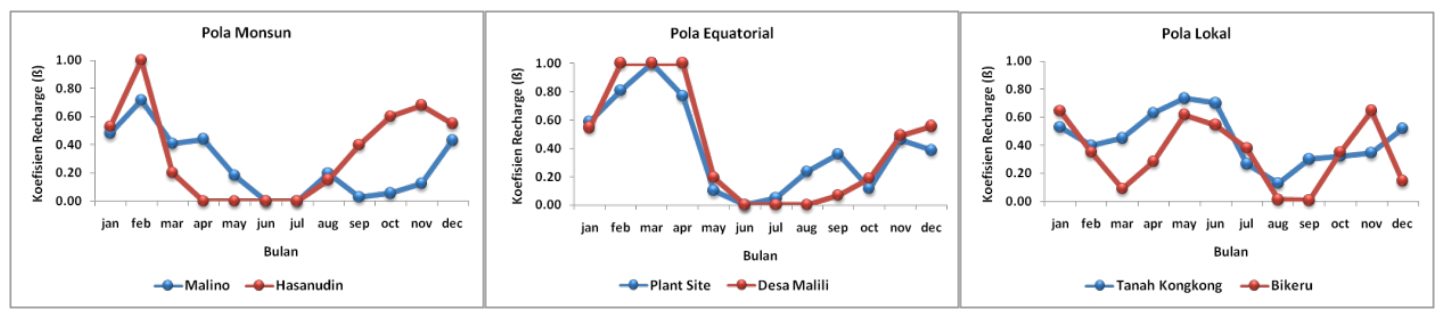

Gambar 3 Fluktuasi koefisien recharge ( $\beta$ ) dari enam stasiun di Sulawesi Selatan

Koefisien runoff $(\mathrm{Y})$ menunjukkan besarnya curah hujan yang mengalir menjadi runoff (limpasan permukaan) dan koefisien ini memiliki kisaran nilai antara 0 sampai 1 . Nilai $Y$ sebagian besar mengikuti bentuk pola hujannya. Untuk stasiun dengan pola hujan monsun dan equatorial, nilai y mengalami penurunan pada bulan April-Mei dan mendekati 0 memasuki bulan Juli-Agustus, selanjutnya kembali naik pada bulan September-Oktober yang merupakan awal musim hujan. Letak perbedaan antara kedua pola hujan tersebut adalah nilai y pada pola hujan equatorial lebih fluktuatif. Stasiun di wilayah dengan pola hujan lokal memiliki nilai yang berkebalikan dengan pola hujan lainnya. Hal ini dikarenakan adanya pengaruh daerah setempat (lokal) terhadap iklim di wilayah tersebut (Gambar 4)

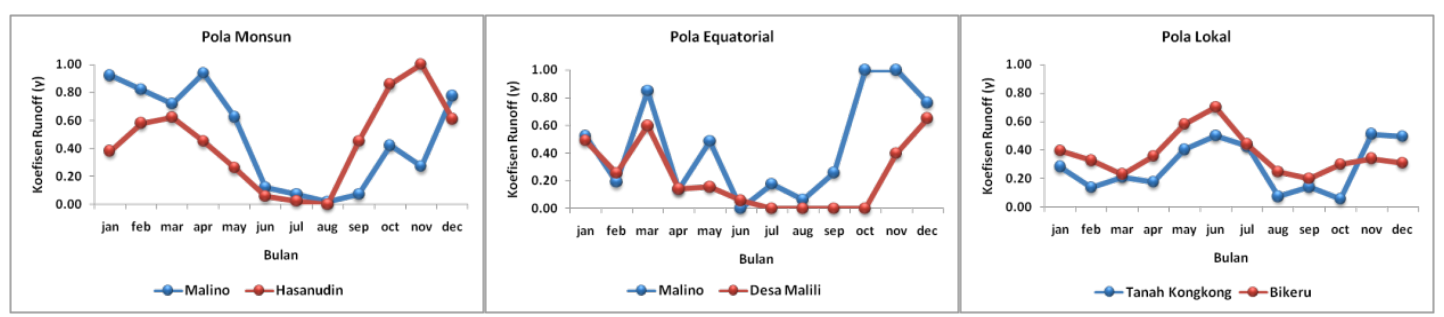

Gambar 4 Fluktuasi koefisien runoff ( $\mathrm{Y}$ ) dari enam stasiun di Sulawesi Selatan 
Koefisien Loss $(\delta)$ atau koefisien kehilangan lengas menunjukkan hasil yang berkebalikan dengan tiga parameter iklim sebelumnya. Hasil perhitungan nilai $\delta$ pada stasiun dengan pola hujan monsun dan equatorial. Saat memasuki bulan Mei (bulan kering) nilai $\delta$ terus meningkat mendekati 1 hingga akhir bulan Agustus dan menurun mendekati 0 pada bulan berikutnya (Gambar 5). Untuk pola hujan equatorial fluktuasi nilai $\delta$ berlangsung lebih singkat daripada pola hujan monsun.

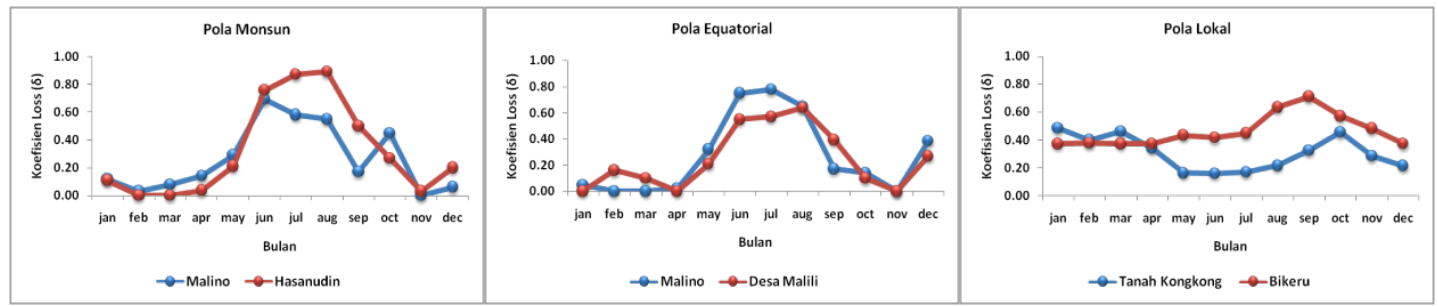

Gambar 5 Fluktuasi koefisien loss ( $\delta$ ) dari enam stasiun di Sulawesi Selatan

\section{Indeks Kekeringan}

Sebaran kekeringan pada bulan Desember-Februari (DJF) pada tahun ENSO menunjukkan sebagian besar wilayah Sulawesi Selatan mengalami awal selang kering menurut kriteria Palmer. Namun ada sebagian daerah di bagian utara dan selatan yang mengalami tingkat kekeringan hingga sangat kering, yaitu kabupaten Mamuju dan kabupaten Maros yang samasama memiliki pola hujan monsun. Ketika memasuki periode Maret - Mei (MAM) yang merupakan peralihan, wilayah Sulawesi Selatan sebagian besar mengalami pergeseran tingkat kekeringan. Pergeseran yang terjadi sangat beragam mulai dari ekstrem basah di bagian tengah yaitu di kabupaten Bone, hingga ekstem kering di bagian utara, yaitu kabupaten Mamuju. Hal ini dikarenakan adanya pengaruh curah hujan bulan sebelumnya terhadap ketersedian air tanah di daerah tersebut.

Pada periode Juni - Agustus (JJA) sebagian besar wilayah Sulawesi Selatan mengalami kekeringan dengan selang kering hingga sangat kering. Kekeringan secara merata terjadi di seluruh wilayah pola monsun, sebarannya antara awal selang kering hingga sangat kering dimana pada bulan JJA terjadi penurunan intensitas curah hujan di bawah normal akibat pengaruh ENSO. Pada pola equatorial sebaran kekeringan pada bulan JJA adalah normal. Bulan September-Oktober (SON) merupakan peralihan dari musim kemarau ke musim hujan. Sebagian besar wilayah Sulawesi Selatan mengalami kekeringan khususnya bagian barat. Wilayah di bagian barat Sulawesi Selatan sebagian besar mengalami kekeringan memasuki bulan SON dengan kriteria kekeringan antara awal selang kering hingga ekstrem kering. 
Hasil perhitungan indeks kekeringan menunjukkan adanya sebaran indeks kekeringan dengan kisaran yang sangat besar antara nilai terendah dan tertingginya. Kedua nilai tersebut terjadi pada wilayah stasiun Hasanudin dengan nilai terendah -22.71 pada bulan Februari 1992 dan tertinggi 18.23 pada bulan Februari 1998, serta rata-rata indeks kekeringannya sekitar 0.3. Selang nilai yang besar tersebut terjadi karena stasiun Hasanudin memiliki fluktuasi curah hujan yang tinggi. Kisaran nilai untuk stasiun lainnya (Tabel 2).

Tabel 2 Indeks kekeringan di enam stasiun terpilih di Sulawesi Selatan

\begin{tabular}{llrrr}
\hline \multirow{2}{*}{ Pola Hujan } & \multicolumn{1}{c}{ Stasiun } & \multicolumn{2}{c}{ Indeks Kekeringan } \\
& & Min & Max & Rataan \\
\hline \multirow{2}{*}{ Lokal } & Tanah Kong & -8.57 & 1.25 & 0.04 \\
& Bikeru & -6.16 & 10.07 & 0.53 \\
\multirow{2}{*}{ Monsun } & Hasanudin & -22.71 & 18.23 & 0.32 \\
& Malino & -0.79 & 4.73 & 0.39 \\
Equatorial & Desa Malili & -0.88 & 1.23 & 0.22 \\
& Plant Site & -4.03 & 5.07 & 0.11 \\
\hline
\end{tabular}

Secara umum indeks kekeringan pada tahun El-Nino bernilai negatif antara 5 hingga 6 bulan berturut-turut, bahkan ada sebagian wilayah yang mengalami indeks kekeringan bernilai negatif lebih dari 6 bulan hingga berlanjut pada tahun berikutnya. Sebagai contoh, tahun 1997 merupakan tahun El-Nino dengan skala kuat, dimana pada tahun tersebut stasiun Hasanudin memiliki indeks negatif selama lebih dari 6 bulan berturut-turut antara bulan Juni hingga Januari tahun berikutnya.

\section{Hubungan Antara Curah Hujan dan Indeks Kekeringan}

Untuk mengetahui sejauh mana keeratan hubungan antara curah hujan dan indeks kekeringan, maka dilakukan uji korelasi. Korelasi tersebut dihitung dengan rumus korelasisilang (Panofsky dan Brier 1958) menggunakan korelasi lag0, yaitu korelasi antara curah hujan dan indeks kekeringan pada bulan yang sama. Selain itu di uji pula korelasi lag1, yaitu korelasi antara indeks kekeringan dengan curah hujan satu bulan sebelumnya, dan lag2, yaitu korelasi antara indeks kekeringan dengan curah hujan dua bulan sebelumnya (Tabel 3). 
Tabel 3 Koefisien korelasi curah hujan dan indeks kekeringan di provinsi Sulawesi Selatan.

\begin{tabular}{|c|c|c|c|c|}
\hline \multirow{2}{*}{$\begin{array}{l}\text { Pola } \\
\text { Hujan }\end{array}$} & \multirow{2}{*}{$\begin{array}{l}\text { Nama } \\
\text { Stasiun }\end{array}$} & \multicolumn{3}{|c|}{ Koefisien Korelasi } \\
\hline & & Lag0 & Lag1 & lag2 \\
\hline \multirow{15}{*}{$\begin{array}{l}5 \\
\text { ज़ } \\
\text { Dे } \\
\Sigma\end{array}$} & Babana & 0.125 & 0.181 & 0.143 \\
\hline & Belajen & 0.184 & 0.370 & 0.112 \\
\hline & Binanga & 0.054 & 0.330 & 0.495 \\
\hline & Hasanudin & 0.468 & 0.658 & 0.268 \\
\hline & Malino & 0.438 & 0.462 & 0.314 \\
\hline & PG. Bone & 0.229 & 0.564 & 0.474 \\
\hline & BPP. Ma'rang & 0.296 & 0.355 & 0.239 \\
\hline & Camming & 0.367 & 0.376 & 0.344 \\
\hline & Lariang & 0.268 & 0.303 & 0.168 \\
\hline & Mattampa & 0.349 & 0.357 & 0.217 \\
\hline & Pakaterang & 0.267 & 0.334 & 0.125 \\
\hline & Sendana & 0.532 & 0.390 & 0.258 \\
\hline & To'ao & 0.493 & 0.292 & 0.136 \\
\hline & Wonomulyo & 0.633 & 0.416 & 0.326 \\
\hline & Rata-rata & 0.336 & 0.385 & 0.259 \\
\hline \multirow{11}{*}{ 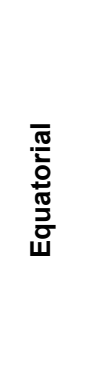 } & Anabanua & 0.348 & 0.318 & 0.132 \\
\hline & Desa Malili & 0.434 & 0.527 & 0.208 \\
\hline & Masamba & 0.096 & 0.277 & 0.259 \\
\hline & Panakukang & 0.816 & 0.747 & 0.635 \\
\hline & Plant Site & 0.400 & 0.656 & 0.240 \\
\hline & BPP. Palanro & 0.354 & 0.446 & 0.228 \\
\hline & Larompong & 0.752 & 0.674 & 0.614 \\
\hline & Malanroe & 0.375 & 0.649 & 0.292 \\
\hline & Pekabata & 0.471 & 0.509 & 0.379 \\
\hline & Paneki & 0.642 & 0.558 & 0.469 \\
\hline & Rata-rata & 0.469 & 0.536 & 0.346 \\
\hline \multirow{6}{*}{$\begin{array}{l}\overline{\widetilde{J}} \\
\text { वे }\end{array}$} & Batukaropa & 0.397 & 0.274 & 0.294 \\
\hline & Bikeru & 0.524 & 0.484 & 0.249 \\
\hline & Kajang & 0.667 & 0.614 & 0.173 \\
\hline & Mattalang & 0.361 & 0.372 & 0.491 \\
\hline & TanaKong & 0.466 & 0.453 & 0.274 \\
\hline & Rata-rata & 0.483 & 0.439 & 0.296 \\
\hline
\end{tabular}

Hasil uji korelasi untuk ketiga jenis pola hujan menunjukkan bahwa indeks kekeringan di Sulawesi Selatan sangat dipengaruhi oleh fluktuasi curah hujan pada bulan yang sama dan fluktuasi curah hujan pada satu bulan sebelumnya. Sedangkan curah hujan dua bulan sebelumnya tidak begitu besar mempengaruhi tingkat kekeringan pada masing-masing pola hujan. Perbedaan respon masing-masing wilayah terhadap penurunan curah hujan terjadi karena adanya pengaruh iklim lokal seperti suhu, jenis dan tekstur tanah, topografi, jenis penutupan lahan karena vegetasi akan mampu menahan dan menyimpan cadangan air lebih lama, sehingga kelengasan tanah tetap terjaga meskipun terjadi penurunan curah hujan.

\section{Hubungan Antara Indeks Kekeringan dan Puso}

Kejadian El-Nino kuat pada Mei 1997 hingga Mei 1998 meningkatkan jumlah lahan puso yang sangat tinggi dibandingkan dengan tahun 1996 (normal) atapun tahun 1998 (La-Nina) dengan rata-rata puso per bulan sebesar 2771 Ha selama periode Juni hingga Oktober. Peningkatan puso tidak selalu diikuti oleh kejadian ENSO, karena di tahun 1996 yang 
merupakan tahun normal juga terjadi peningkatan puso, yaitu pada bulan Oktober sebesar 20 Ha. Peningkatan puso tidak selalu disebabkan oleh kejadian ENSO, karena puso lahan juga dapat terjadi pada tahun-tahun normal. Peningkatan puso tersebut disebabkan karena adanya penurunan curah hujan pada bulan JJA yang merupakan puncak musim kemarau, sehingga berpengaruh pada bulan berikutnya, yaitu bulan September-Oktober-Desember (SON).

Tahun 1998 merupakan tahun La-Nina, dimana pada tahun ini tidak terjadi peningkatan lahan puso akibat kekeringan, namun peningkatan lahan puso lebih disebabkan karena banjir akibat adanya peningkatan curah hujan di atas normal. Kejadian ENSO yang menyebabkan kekeringan ekstrem akan memberikan dampak nyata terhadap peningkatan puso lahan, baik akibat kekeringan ataupun banjir (Gambar 6)

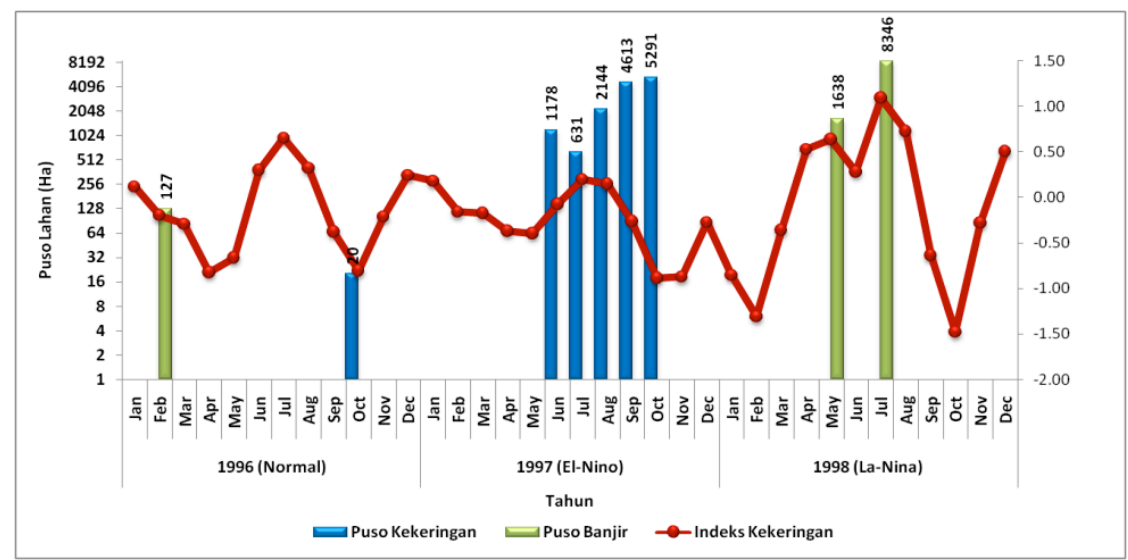

Gambar 6 Grafik hubungan antara indeks kekeringan dan puso lahan tahun 1996 - 1998

\section{Verifikasi Indeks Kekeringan}

Kekeringan yang terjadi selama periode waktu pengamatan (1985-2002) dijumpai di setiap stasiun pengamatan di Sulawesi Selatan. Menurunnya produksi tanaman umumnya disebabkan oleh kekeringan, namun tidak selamanya berlaku demikian karena masih banyak faktor lain yang mempengaruhi, misalnya serangan hama/penyakit, banjir (penggenangan), maupun faktor tak terduga lainnya (Williams dan Joseph 1975).

Pengaruh indeks kekeringan terhadap luas panen dan produksi (Gambar 7 dan 8). Saat kejadian El-Nino, penurunan luas panen pada padi ladang lebih nyata daripada padi sawah dan kedua tanaman lainnya. Hal ini dikarenakan kebutuhan air pada padi ladang hanya bersumber dari curah hujan, sehingga jenis padi ini lebih rentan terhadap penurunan curah hujan. Berbeda dengan padi ladang, padi sawah lebih tahan terhadap kekeringan karena jenis padi ini tidak hanya memperoleh sumber air dari hujan, tetapi juga dari irigasi. Sedangkan untuk tanaman palawija yaitu jagung dan kedelai tidak terjadi penurunan luas panen secara signifikan, kecuali pada kejadian ENSO sangat ekstrem. 


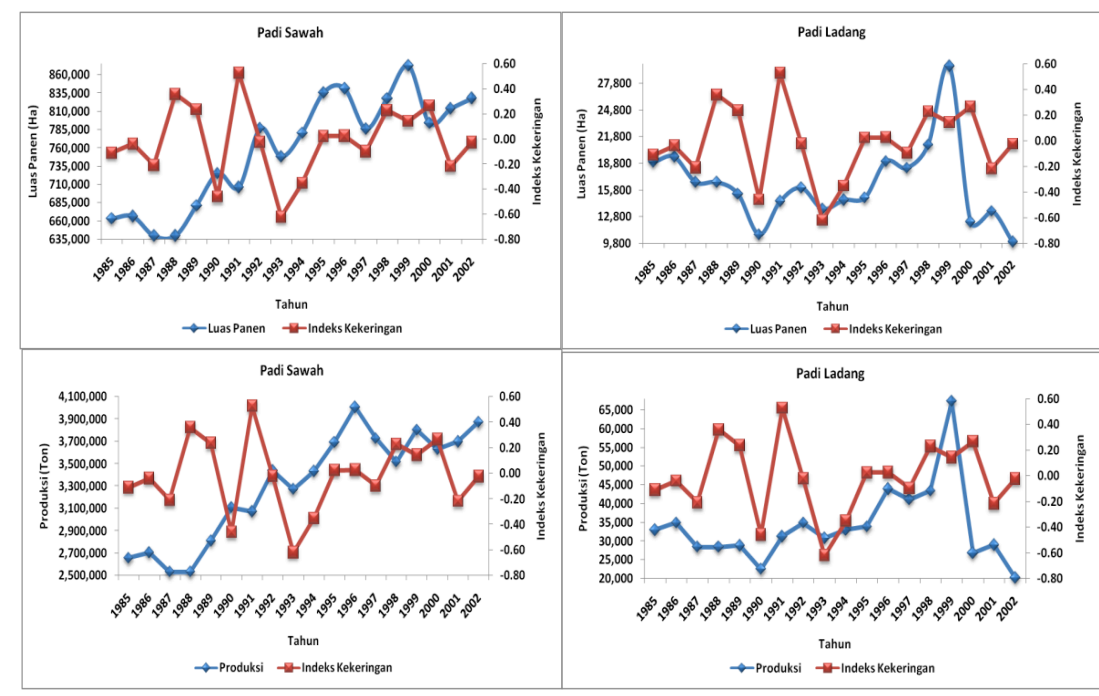

Gambar 7 Hubungan indeks kekeringan terhadap luas panen dan produksi tanaman pangan.

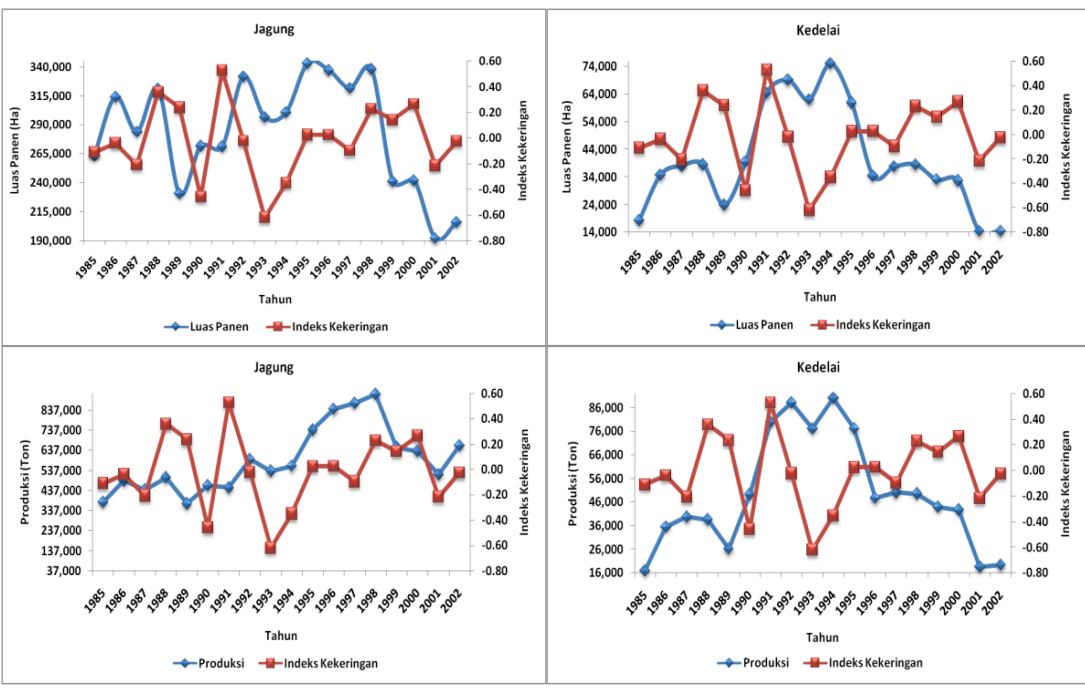

Gambar 8 Hubungan indeks kekeringan terhadap luas panen dan produksi tanaman palawija.

Penurunan luas panen akibat ENSO secara langsung akan berpengaruh terhadap jumlah produksi tanaman. Setiap kejadian ENSO selalu diikuti oleh penurunan jumlah produksi tanaman padi, terutama jenis padi ladang (Gambar 7 ). Sedangkan untuk tanaman palawija produksinya cenderung meningkat pada setiap kejadian ENSO, kecuali untuk tanaman jagung dimana produksinya akan menurun pada saat ENSO lemah, misalnya pada tahun 1994 (Gambar 8). Ini menunjukkan tanaman palawija lebih adaptif terhadap kekeringan, karena kebutuhan air tanaman yang tidak sebanyak tanaman padi. Salah satu antisipasi terhadap penurunan produksi adalah dengan mengganti komoditas padi pada kondisi ENSO sebagai kompensasi terhadap penurunan produksi padi. Sedangkan pada kondisi ENSO kuat perluasan areal tanaman palawija dapat dilakukan sebagai solusi meminimalisasi penurunan produksi. 


\section{KESIMPULAN DAN SARAN}

\section{Kesimpulan}

Selama periode 1985-2002 Sulawesi Selatan seringkali mengalami kekeringan akibat ENSO dengan tingkat kekeringan yang beragam menurut kriteria Palmer, mulai dari ekstrem kering hingga ekstrem basah. Kejadian ENSO pada daerah dengan pola hujan monsun berpengaruh kuat, lemah pada daerah dengan pola hujan equatorial dan tidak jelas pengaruhnya pada daerah dengan pola hujan lokal.

Produksi tanaman padi pada setiap kejadian ENSO menurun, terutama untuk jenis padi ladang. Sedangkan untuk tanaman palawija secara umum produksi tanaman meningkat pada setiap kejadian ENSO karena tanaman palawija sebagian besar merupakan tanaman yang tahan terhadap kekeringan, terutama varietas lokal yang sudah beradaptasi dengan baik terhadap lingkungannya.

\section{Saran}

Perlu dilakukan penelitian lebih lanjut mengenai indeks kekeringan ini, lebih utama apabila dilakukan survei lapang, sehingga kita bisa lebih tahu keadaan iklim yang terjadi sebenarnya di daerah kajian. Pengujian indeks kekeringan dan data produksi sebaiknya menggunakan level kabupaten, agar cakupannya lebih mendetail, sehingga hasil yang diperoleh pun lebih mendekati kenyataan dilapangan.

\section{DAFTAR PUSTAKA}

[Bakosurtanal] Badan Koordinasi Survey dan Pemetaan Nasional. 1975. Peta Jenis Tanah Provinsi Sulawesi Selatan. Bogor : Bakosurtanal.

[BMKG] Badan Meteorologi, Klimatologi, dan Geofisika. 1990. Peta Pola Curah Hujan Indonesia. http://www.bmg.go.id. [21 Desember 2009].

Boer, R. 1999. Perubahan Iklim, El-Nino dan Li-Nina. Makalah Pelatihan Dosen-dosen Perguruan Tinggi Indonesia Bagian Barat dalam Bidang Agroklimatologi. Biotrop-Bogor. 1-12 Februari.

Boerema, J. 1933. Maps of the Mean Annual Monthly Rainfall in Celebes. Verhandelingen, Koninklijk Madnetisch en Meteorologisch Observatorium, Batavia, No.8. 545p.

[BPS] Badan Pusat Statistik. 2003. Buku Pedoman Petugas Kabupaten/Kota dan Propinsi, Pengumpulan Data Tanaman Pangan dan Palawija. Jakarta : BPS.

Bruce, J. P. and R.H. Clark. 1966. Introduction to Hydrometeorology. Pergamon press. Oxford.

Critchfield. H. J. 1979. General Climatology. Prentice Hall India.

De Boer, H. J. 1947. On Forcasting the Beginning and the End of Dry Monsoon in Java and Madura. Verhandelinge No. 32. Batavia. 
[Dephut] Departemen Kehutanan. 2002. Data dan Informasi Kehutanan Provinsi Sulawesi Selatan. Jakarta : Badan Planologi Kehutanan.

[Deptan] Departemen Pertanian. 1967. Survey Dasar Dalam Rangka Pembangunan Pertanian Sulawesi Selatan Jilid IIA-IIB. Bogor : Lembaga Penelitian Tanah.

Direktorat Perlindungan Tanaman. 2006. Luas Banjir pada Tanaman Padi tahun 1998-2005. Direktorat Perlindungan Tanaman, Direktorat Jendral Bina Produksi Tanaman Pangan. Jakarta : http://www.deptan.go.id

Doorenbos, J and W.O Pruitt. 1975. Crop Water Requirements. Food and Agricultural Organization (FAO). Rome. 193 p.

Historiawati. 1987. Analisa Sebaran Kekeringan Daerah Semarang, Demak dan Purwodadi Grobogan. [Skripsi]. Jurusan Geofisika dan Meteorologi. Fakultas Matematika dan IImu Pengetahuan Alam. Institut Pertanian Bogor.

Hounam, C. E., J.J. Burgos, M.S. Kalik, W.C. Palmer, dan J. Rodda. 1975. Drought and Agriculture. Technical note no. 138. World Meteorological Organization.

Howell, D.C. 1989. Fundamental Statistic for the Behavioral Science (second ed.). PWS Kent Publishing Company-Boston. 368p.

Jasis dan A.S Karama. 1998. Kebijakan Departemen Pertanian Dalam Mengantisipasi Iklim. Prosiding Antisipatif Menghadapi Gejala Alam La-Nina dan El-Nino. Kerjasama PERHIMPI dengan Jurusan GEOMET-IPB, Puslittanak dan ICSEA.

Lakitan, Benyamin. 2002. Dasar-Dasar Klimatologi. Cetakan Kedua. Raja Grafindo Persada. Jakarta.

National Weather Service, Climate Prediction Center NOAA, 2002, UV Index: Information, http://www.nws.noaa.gov [13 Januari 2010].

Oldeman, L. R. 1975. An Agro-climatic map of South Sulawesi. Contr. Centr. Res. Inst. Agric. Bogor. No. 17.

Palmer, W. C. 1965. Meteorological Drought. Research Paper No. 45. US Weather Bureau, Washington, D.C.

Panofsky, H.A. and G.W. Brier. 1958. Some Applications of Statistics to Meteorologi. University Park. Pensylvania.

PIRBA, 2008. Kekeringan. http://www.pirba.ristek.go.id. [20 Desember 2009].

Sudibyakto. 1985. Evaluasi Kekeringan di Daerah Kedu Selatan dengan Menggunakan Indeks Palmer. [Tesis]. Fakultas Pasca Sarjana. Institut Pertanian Bogor.

Siswanto, B., 1999, "Simulasi Fenomena ENSO Berbasis Model Sirkulasi Global". Jurnal LAPAN, vol. 1, no. 3.

Trenberth, K. E., 1997. The Definition of El-Nino. Bull. Amer. Meteor. Soc. 2771-2777.

Thornthwaite, C.W. dan J.R. Mather. 1957. Instruction and Table for Computing Potential Evapotranspiration and The Water Balance. Drexel Institute of Technology. Laboratory of Climatology. Centerton, New Jersey, USA.

Tjasyono, B. 1997. Mekanisme fisis para, selama, dan pasca El-Nino. Paper disajikan pada Workshop Kelompok Peneliti Dinamika Atmosfer, 13-14 Maret 1997.

Trenberth, K.E. 1997. The Definition of El-Nino. Bul. Amer. Meteor. Soc. 2771-2777. 
Turyanti, A. 1995. Sebaran Indeks Kekeringan Wilayah Jawa Barat. [Skripsi]. Jurusan Geofisika dan Meteorologi. Fakultas Matematika dan IImu Pengetahuan Alam. Institut Pertanian Bogor.

Winarso, A.P 2002. Variabilitas dan Perubahan Iklim di Indonesia hingga 2002. BMG. Jakarta. 